\title{
A Comparative Study of Lecture and Discussion Methods in the Education of Basic Life Support and Advanced Cardiovascular Life Support for Medical Students
}

\author{
Tıp Öğrencileri iç̧in Temel Yaşam Desteği ve İleri Kardiyovasküler Yaşam Desteği \\ Eğitiminde Ders Verme ve Tartışma Yöntemlerinin Karşılaş̧ırmalı Çalışması
}

\author{
Peyman HAFEZIMOGHADAM, Sahar FARAHMAND, Davood FARSi, \\ Mohammadamin ZARE, Saeed ABBASi \\ Department of Emergency Medicine, Tehran University of Medical Sciences, Iran
}

\begin{abstract}
SUMMARY
\section{Objectives}

The goal of this study was to compare lecture and small-group discussion methods for educating medical students in emergency department.

\section{Methods}

Over a 2-year period, 155 fourth to fifth-year medical students in the emergency department were given educational sessions on basic life support (BLS) and adult advanced Cardiovascular Life Support (ACLS). These sessions were given by a single instructor in a traditional lecture format, in a small-group discussion, or in a combination of these two methods. Prior to the instructional sessions, students anonymously completed a 20-question multiple-choice examination on the covered topics. At the completion of sessions, students repeated the same multiple-choice examination. They also completed an evaluation form on the instructional format, using a 5-point Likert scale, ranging from 1 (strongly agree) to 5 (strongly disagree).
\end{abstract}

\section{Results}

There was a significantly higher level of enjoyment in the combination group (lecture plus discussion), although there were no differences in the test scores immediately after the instructional sessions.

\section{Conclusions}

Medical students learning about BLS and ACLS preferred a combination of lecture and small-group discussions over traditional lectures or discussion groups. However, this preference did not lead to improved test scores on these subjects.

Key words: Group discussion; lecture; teaching.

\section{ÖZET}

Amaç

Bu çalışmanın amacı acil serviste tıp öğrencilerinin eğitiminde ders verme ve küçük gruplu tartışma yöntemlerini karşılaştırmaktı.

\section{Gereç ve Yöntem}

İki yıl içinde toplam 155 dördüncü ve beşinci sınıf tıp öğrencisi için acil serviste temel yaşam desteği (TYD) ve erişkinde ileri kardiyovasküler yaşam desteği (IKYD) üzerine eğitsel toplantılar düzenlenmiştir. Bu toplantılarda tek bir eğitmen geleneksel ders formatı, küçük gruplu tartışma veya bu iki yöntemin kombinasyonunu uygulamıştır. Eğitsel toplantılardan önce öğrenciler adlarını yazmadan kapsanan konular hakkında 20 soruluk çoktan seçmeli bir sınavdan geçmiştir. Dersler tamamlandığında öğrenciler tekrar aynı çoktan seçmeli sınavdan geçmiştir. Öğrenciler ayrıca, 1 (kesinlikle olumlu) ila 5 (kesinlikle olumsuz) arası puanlama yapan Likert ölçeğini kullanarak bir eğitimi değerlendirme formunu doldurmuştur.

\section{Bulgular}

Kombinasyon grubundan (ders artı tartışma) anlamlı derecede daha çok hoşlanılmasına rağmen eğitsel oturumlardan hemen sonra test puanlarında hiçbir farklılık yoktu.

\section{Sonuç}

TYD ve İKY konularını öğrenen tıp öğrencileri geleneksel ders ve tartışma grupları yerine ders ve küçük gruplu tartışmaların kombinasyonunu tercih etmiştir. Ancak bu tercih bu konularda test puanlarının iyileşmesine yol açmamıştır.

Anahtar sözcükler: Grup tartışması; ders; öğretim. 


\section{Introduction}

One important step in educational design is choosing a teaching method. Traditional lectures often focus on memorization rather than the comprehension and use of information. Lecturing is one of the primitive and maybe the oldest method of teaching, and it is currently the most conventional educational technique. In this approach, students silently and passively receive information ${ }^{[1]}$ However, active participation and cooperation of students often leads to better, more effective and permanent learning. Because of this, educational experts emphasize the use of modern comprehensive methods, ${ }^{[2]}$ which help students better understand and remember information. ${ }^{[3]}$

In various studies, the conventional lecturing method has failed to transfer concepts to students as effectively as active learning approaches such as small group tasks and discussions. Therefore, it has been suggested that it is better to use the conventional lectures only for transferring data to students. ${ }^{[4]]}$ In contrast to these studies, others have reported that both teaching methods have equal impact on learning. Lectures continue to be the most used education method since they save time and resources that are used in more active learning techniques. ${ }^{[8-10]}$

Botelho and O'Donnell's research has shown that teaching via small group discussions creates an active learning environment for all students, including those with all levels of intelligence and mental ability. They suggested that teaching in a group discussion format with two-sided data exchange is most efficacious for students. They have also emphasized that students prefer learning in active lectures with an expert faculty who predominates the educational discussion. [11] Hiill's comparison between lecturing and discussion showed that students' mental abilities and skills are higher in group discussions and that this approach is useful for remembering information. ${ }^{[12]}$ Roche has also reported that by combining lectures with group tasks, the students' attitudes towards the subject would become better more quickly. ${ }^{[13]}$

These two techniques have been compared in various medical educational groups. For example, dentistry students showed that the combined methods led to increased student satisfaction and inner motivation, which led to higher educational quality. ${ }^{[14]}$ In nursing students, the combined teaching method improved their communication skills in the clinical environment. ${ }^{[15]}$

Medical students need to learn the skills of problem solving and decision making in addition to receiving data and knowledge. Since cardiopulmonary resuscitation is a lifesaving maneuver that can save the patient from definite death, it is of high importance for medical staff. Therefore, we studied the effects of different teaching methods for Ba- sic life support and Adult advanced cardiovascular life support in medical students.

\section{Materials and Methods}

This study was performed with 155 of fourth or fifth year medical students. Due to the clinical importance of being familiar with primary and advanced resuscitation techniques for cardio-pulmonary arrest patients based on American Heart Association latest guidelines, we chose this topic for teaching. Students were randomly divided into three groups: traditional lecture, group discussion, and lecture plus group discussion. For all three groups, we performed 3 educational sessions of 50 minutes each. Based on their teaching type, we gave the students the performance protocol for each group, which included the list of lessons to be learned, a step by step manual of teaching performance, and goals of the class.

The traditional lecture session was carried out in a large classroom with plentiful light and audiovisual equipment including a white-board, video projector, and teaching slides. In the beginning, the aim of the class was explained, and during the session we tried to increase the students' attention by asking questions, giving examples, and making conclusions and outlines. There were 3 topics to discuss, which took a total time of 3 hours ( 50 minutes for each topic and 10 minutes of questions and answers).

In the group discussion session, students were divided into 5 groups of 10, and they were guided by an instructor (a total of 5 mutual instructors) through scenarios covering the assigned subjects. All of the needed material was given to the students in advance. This session was performed in a 3 hour period as a whole. In the third group, first, a 30 minute lecture was given for each topic followed by a 20 minute group discussion guided by instructors in groups of 10 . The content was similar in all 3 groups and we used uniform slides.

In all three sessions, we completed forms containing the students' demographic data and characteristics, and then gave them a pre-test questionnaire with a 20 minute time limit. At the end of the program they completed a similar post-test as well as an evaluation form. The pre and post-test each contained 20 questions in multiple-choice format with the same value. The validity of the tests' contents was confirmed by 5 respectful emergency medicine academic members of Tehran University of Medical Sciences. The quality of teaching was evaluated with a form added at the end of the post-test questionnaire, which contained five sentences with answers adjusted using a 5-point Likert scale (including: strongly agree, agree, no opinion, disagree, strongly disagree). These statements evaluated the way the class was handled (how, who, when, where). 


\section{Sample Size}

Based on the number of students present in Rasoul Akram hospital during our research time, after coordination with university authorities, and after a 20 percent drop in participants, a total of 155 students (in their 4th or 5th year) were enrolled in the study and were randomly divided into three groups.

\section{Data Analysis Method}

Comparison of the difference between the score of pre and post-tests was analyzed by a Paired t-test. For all three groups, we used variance analysis for quantitative variables and Chi squared tests for qualitative variables. A p value of less than 0.05 was accepted as significant. All statistical calculations were performed using the SPSS software program (version release 13.0, SPSS, Inc., Chicago, IL).

\section{Results}

In this study, three groups with a total number of 155 students were enrolled in the study. Fifty two students were in the lecture group, 50 were in the group discussion, and 53 were in the combined lecture and group discussion class. The participants were aged between 21 and 26 years (mean $22.7 \pm 2.3$ years) and all of them were in their 8 th to 10 th term of their medical education. Ninety six of them (61.9 percent) were female students.

The pre-test mean score in the lecture group was $53.3 \pm 16.3$ and after the lecture it was $89.5 \pm 5.8$. In the group discussion session, the pre-test had a mean score of $45.0 \pm 13.1$ and the post-test mean score of this group was $85.6 \pm 9.6$. In the lecture and discussion group, the mean score of the pre and post-test were $47.8 \pm 14.6$ and $89.8 \pm 5.9$, respectively. Using a $\mathrm{t}$-paired test, the differences between the pre and post-test scores for each group were significant (Table 1).

For comparing the effectiveness of three mentioned methods, a variable showing the difference between pre-test and post-test score was calculated. The mean increase of scores was $36.2 \pm 15.9$ in the lecture group, was $40.6 \pm 13.0$ for those in group discussion, and was $43.0 \pm 13.8$ in the lecture plus group discussion group. According to an ANOVA test, these differences were not statistically significant (Table 2).

Based on a 5-point Likert scale, participants evaluated the overall session, the session moderator, and the timing and place of that session. Using a Kruskal Wallis test, there was no significant difference between the groups. At the end of each session and right before the post-test, students were asked about how satisfied they were with their sessions. According to their comments, the mean satisfaction in the

Table 1. Mean score of pre-test and post-test of three groups

\begin{tabular}{lcccc}
\hline Group & Mean & N & Std. Deviation & Sig. (2-tailed)* \\
\hline Lecture & & & & \\
$\quad$ Pretest & 53.27 & 16.296 & 16.296 & 0.000 \\
$\quad$ Posttest & 89.52 & 5.796 & 5.796 & \\
Group discussion & & & & 0.000 \\
$\quad$ Pretest & 45.00 & 13.054 & 13.054 & \\
$\quad$ Posttest & 85.60 & 9.564 & 9.564 & 0.000 \\
Lecture and group discussion & & & & \\
$\quad$ Pretest & 47.75 & 14.580 & 14.580 & \\
$\quad$ Posttest & 90.75 & 5.916 & 5.916 & \\
\hline
\end{tabular}

*Paired Samples Test.

Table 2. Difference between pre-test and post-test in each group

\begin{tabular}{lcccccc}
\hline Group & N & Minimum & Maximum & Mean & Std. Deviation & Sig. * \\
\hline Lecture & 52 & 5.00 & 75.00 & 36.2500 & 15.96181 & .054 \\
Group discussion & 50 & 10.00 & 70.00 & 40.6000 & 13.03997 & \\
Lecture and group discussion & 53 & 15.00 & 70.00 & 43.0000 & 13.79381 & \\
*OneWay ANOVA. & & & & & &
\end{tabular}


Table 3. Comparison of participants satisfaction according to Kruskal Wallis

\begin{tabular}{|c|c|c|c|c|}
\hline & Group & $\mathbf{N}$ & Mean Rank & Sig. \\
\hline \multirow[t]{3}{*}{ Satisfaction from performance method } & Lecture & 52 & 76.07 & .562 \\
\hline & Group discussion & 50 & 82.50 & \\
\hline & Lecture and group discussion & 53 & 75.65 & \\
\hline \multirow[t]{3}{*}{ Satisfaction from presenter } & Lecture & 52 & 73.65 & .272 \\
\hline & Group discussion & 50 & 84.42 & \\
\hline & Lecture and group discussion & 53 & 76.21 & \\
\hline \multirow[t]{3}{*}{ Satisfaction from time of the class } & Lecture & 52 & 81.13 & .665 \\
\hline & Group discussion & 50 & 74.26 & \\
\hline & Lecture and group discussion & 53 & 78.45 & \\
\hline \multirow[t]{3}{*}{ Satisfaction from place of class } & Lecture & 52 & 84.82 & .267 \\
\hline & Group discussion & 50 & 77.31 & \\
\hline & Lecture and group discussion & 53 & 71.96 & \\
\hline
\end{tabular}

lecture group was $87.9 \%$, was $89 \%$ in the group discussion group, and was $94 \%$ in the lecture plus group discussion group. A one-way ANOVA test showed that differences between the groups were not statistically significant $(\mathrm{Sig}=0.04)$ (Table 3).

\section{Discussion}

The results of this research have shown that all three educational methods were able to effectively increase the students' knowledge on the topics. A comparison of pre-test and post-test scores of all three groups showed elevation in scores, but the differences in the average scores were not statistically significant. All three methods increased the students' post-test scores, but there was not a significant difference between the three sessions. There might not have been a difference because there were limited sessions, there was a high load of academic content in proportion to the time and number of sessions, and because of the type of the educational content.

The outcome of our study confirmed the published study of Fischer and colleagues in 2004. In that study, the methods of lecture and small group discussion were compared, and it was reported that although the students significantly preferred the group discussion to the lecture, there was no significant difference in the post-test scores of the two groups. ${ }^{[16]}$ In another study done by Hanze and Berger in 2007, there was no difference between cooperative and traditional teaching groups in reaching goals, but the cooperative group had a higher motivation, ${ }^{[17]}$ which matches our present results.

The current study shows that in comparison with the lecture technique, teaching with a group discussion approach significantly elevates student satisfaction with the teaching methods. This could be due to the students' obligation to actively cooperate in the discussion, the enforcement of communication skills, and because of the facilitation of the learning process.

\section{Limitations}

Problems we faced in performing this study included difficulty in planning student groups, having concurrent sessions, and determining the pre-guidance of group discussion before the session. Another limitation was the inability to measure the students' clinical skills after each program. Another limitation was a lack of proper space for having group discussion sessions.

In conclusion, the lecture plus group discussion teaching method was as effective and capable as the traditional lecture or group discussion methods in increasing the knowledge of students about basic and advanced life support in patients with cardiopulmonary arrest.

\section{Conflict of Interest}

The authors declare that there is no potential conflicts of interest.

\section{References}

1. Hejazi S. Teaching methods in education. 2nd ed. Tehran: Boshra; 2006.

2. Albanese MA, Mitchell S. Problem-based learning: a review of literature on its outcomes and implementation issues. Acad Med 1993;68:52-81. [CrossRef]

3. Costa ML, van Rensburg L, Rushton N. Does teaching style matter? A randomised trial of group discussion versus lectures in orthopaedic undergraduate teaching. Med Educ 
2007:41:214-7. [CrossRef]

4. Bello-Haas VD, Bazyke S, Ekelman BM. A study comparing the effectiveness of the feedback lectuire method with the traditional lecture method. J Physical Therapy Education 1999;13:36-40.

5. Safari M, Yazdanpanah B, Ghafarian-Shirazi HR. Comparing the effect of lecture and discussion methods on students learning and satisfaction. Iran J Med Edu 2006;1:59-64.

6. Aein FK. Problem-based learning: a new experience in education of pediatric nursing course to nursing students. Shahrekord Univ Med Sci 2006;2:16-20.

7. Hazavehei SMM, Taghdisi MH, Mohaddes Hakak HR. The effects of three teaching methods of lecture, training game and role playing on knowledge and practice of middle school girls in regard to puberty nutrition. J Med Edu Dev of Kerman Uni of Med Sci 2006;2:126-33.

8. Zolfaghari M, Mehrdad N, Parsa-Yekta Z, Barugh Salmani $\mathrm{N}$. The effect of lecture and e-learning method on learning mother and child health course in nursing students. Iran J Med Edu 2007;1:31-9.

9. Salimi T, Shahbazi L, Mojahed SH, Ahmadieh MH. Comparing the effect of lecture and work in group on nursing students skill in calculating medication dosage. Iranian J Medical Edu 2007;1:79-84.

10. Birgegård G, Persson E, Hoppe A. Randomized comparison of student-activating and traditional lecture: no learning differ- ence. Med Teach 2008;30:819. [CrossRef]

11. Botelho MG, O'Donnell D. Assessment of the use of problem-orientated, small-group discussion for learning of a fixed prosthodontic, simulation laboratory course. Br Dent J 2001;191:630-6. [CrossRef]

12. Hill RJ. A comprative study of lecture and discussion methods. Studies in adult group learning in the liberal arts. Available from: http://www.eric.ed.gov/PDFS/ED028375. pdf. Accessed August 22, 2012.

13. Roche WP 3rd, Scheetz AP, Dane FC, Parish DC, O'Shea JT. Medical students' attitudes in a PBL curriculum: trust, altruism, and cynicism. Acad Med 2003;78:398-402. [CrossRef]

14. Momeni-Danaei S, Zarshenas L, Oshagh M, Omid-Khoda SM. Which method of teaching would be better; cooperative or lecture? Iran J Med Edu 2011;11:24-31.

15. Baghcheghi N, Kouhestani H, Rezaei K. Comparison of the effect of teaching through lecture and group discussion on nursing students' communication skills with patients. Iran J Med Edu 2010;10:211-8.

16. Fischer RL, Jacobs SL, Herbert WN. Small-group discussion versus lecture format for third-year students in obstetrics and gynecology. Obstet Gynecol 2004;104:349-53. [CrossRef]

17. Hanze M, Berger R. Cooperative learning, motivational effects, and student characteristics: an experimental study comparing cooperative learning and direct instruction in 12th grade physics classes. Learning and Instruction 2007;17:29-41. [CrossRef] 